\title{
Renewable Energy Deployment to Stimulate Energy Transition in the Gulf Cooperation Council
}

Yagyavalk Bhatt

\subsection{INTRODUCTION}

Electricity consumption in GCC has increased rapidly over the past two decades by around $6 \%$ to $12 \%$ annually due to rising population and economic growth. With a positive economic outlook, this trend is expected to continue. As countries in the GCC are major oil and gas producers, their electricity production has typically relied on oil and gas. However, they are now slowly diversifying away from increased reliance on oil and gas to renewable energy and other sources (King Abdullah Petroleum Studies and Research Center, 2018).

As per the Table 8.1, In the GCC, Saudi Arabia has the highest capacity with about $83.70 \mathrm{GW}$, followed by UAE, and Kuwait. Further, fossil fuels are used as primary source of energy in generation of electricity in all the

\footnotetext{
Y. Bhatt $(\bowtie)$

King Abdullah Petroleum Studies and Research Center (KAPSARC), Riyadh, Saudi Arabia e-mail: yagyavalk.bhatt@kapsarc.org

(C) The Author(s) 2021 in Asia, https://doi.org/10.1007/978-981-15-8905-8_8
} 
Table 8.1 Peak load, available capacity and share of fuel mix in GCC for 2016-2017

\begin{tabular}{|c|c|c|c|c|c|c|}
\hline \multirow[t]{4}{*}{ Country } & \multirow{3}{*}{$\begin{array}{l}\begin{array}{l}\text { Available } \\
\text { capacity }\end{array} \\
\text { Gigawatt }\end{array}$} & \multirow{3}{*}{$\begin{array}{l}\begin{array}{l}\text { Peak } \\
\text { load }\end{array} \\
\text { Gigawatt }\end{array}$} & \multicolumn{4}{|l|}{ Fuel mix } \\
\hline & & & $\begin{array}{l}\text { Natural } \\
\text { gas }\end{array}$ & $\begin{array}{l}\text { Crude } \\
\text { oil }\end{array}$ & $\begin{array}{l}\text { Heavy fuel } \\
\text { oil }\end{array}$ & Diesel \\
\hline & & & \multicolumn{4}{|c|}{ \% offuel mix } \\
\hline & Year 2016-17 & & & & & \\
\hline Saudi Arabia & 83.7 & 60.828 & $45 \%$ & $23 \%$ & $24 \%$ & $8 \%$ \\
\hline United Arab & 29.06 & 21 & $98 \%$ & 0 & $2 \%$ & 0 \\
\hline \multicolumn{7}{|l|}{ Emirates } \\
\hline Kuwait & 18.9 & 13.39 & $99.9 \%$ & 0 & 0 & 0 \\
\hline Qatar & 10.21 & 11 & $100 \%$ & 0 & 0 & 0 \\
\hline Oman & 7.8 & 5.92 & $97 \%$ & 0 & 0 & $3 \%$ \\
\hline Bahrain & 4.82 & 3.418 & $78 \%$ & 0 & $22 \%$ & 0 \\
\hline
\end{tabular}

Source: Kingdom of Bahrain Electricity \& Water Authority, Kuwait Ministry of Electricity \& Water, Oman Power and Water Procurement Company, Qatar Electricity \& Water Corporation, Electricity \& Cogeneration Regulatory Authority, Abu Dhabi Water and Electricity Company, Dubai Electricity and Water Authority, Sharjah Electricity and Water Authority, Federal Energy and Water Authority, KAPSARC data portal

GCC countries, primarily natural gas and crude oil and its products. Bahrain, Oman, Qatar, Kuwait and the UAE use gas for about $90 \%$ of their energy needs. Whereas in Saudi Arabia oil and oil products remain the predominant source. However, Saudi Arabia is transitioning from crude oil and its oil products towards domestic natural gas (International Renewable Energy Agency 2019).

Although, the GCC countries are the major contributor to the global energy markets because of its substantial hydrocarbon resources. Yet the GCC countries have an intent to be a global leaders in renewable energy. All the countries within the GCC have plans to include renewable energy power generation in their energy mix to address the issues of growing energy consumption with high demand for electricity due to development of industries and rise in energy consumption in residential sectors. Further, the energy prices are in GCC are lowest in the world putting them among the highest consumers of energy per capita. If alternative energy sources are not utilized to meet the energy demand, domestic consumption could absorb most of the region's hydrocarbon production. The energy 
diversification will free up hydrocarbon resources for export, foster economic diversification, accelerate strategically vital job creation, and reduce carbon-dioxide (CO2) emissions within GCC countries (World Economic Forum 2017).

The GCC countries are making efforts by reforming their markets to increase sector liberalization and private sector participation, further, by promoting renewable energy technologies and aligning domestic prices of electricity with the true cost of generation (KAPSARC 2017). As renewable energy, especially solar, is becoming a significant part of the global energy system. However, the GCC countries' have their vision and strategies in place, but to achieve them they need a more structured approach for supporting policy development. With abundant renewable energy resources and their leadership in the global energy sector, the current targets are entirely within reach for the GCC countries.

The GCC countries could be the world leaders in renewable energy deployment led by solar PV as the major technology provided current plans and visions are supported with enabling policy framework and renewable energy push driven by GCC's largest energy markets. This chapter explores the current policy intervention for the widespread adoption of renewable energy in GCC, the need for renewable energy and challenges \& opportunities associated with the sector.

\subsection{Promotion of Renewable Energy in GCC}

Renewable energy plans and developments have come a long way in the GCC in recent years, with every country's ambitions differing from its market size and readiness. There has been a push through national vision documents with targets and strategies to promote renewable energy in the GCC. Renewable energy (RE) push alongside energy efficiency is an effort to safeguard natural resources and diversify the energy mix, which remains heavily dominated by fossil fuels.

The GCC countries have also integrated targets for renewable energy in their the United Nations Framework Convention on Climate Change (UNFCCC), Nationally Determined Contributions (NDCs). Some of the countries have also translated these state visions into concrete policy and projects, with short and long term dissemination plans. These policies and development plan particularly seem positive for more significant markets like Saudi Arabia and UAE. 


\subsubsection{Vision and Strategy for Renewable Energy Policies}

GCC countries have come up with a dynamic policy framework (Fig. 8.1), which is necessary to accelerate renewable energy deployment, mainly through firm government commitment to renewable energy with timebound targets and supportive investment mechanisms. Further, dissemination of renewable energy in the GCC has also been due to the creation of dedicated institutions with transparent bidding process for the projects. The GCC aspiration for energy diversification is a very realistic outlook. If current policy visions are backed up with the enabling frameworks for successful implementation of projects, then the future promises to have a significant growth in deployment of renewable energy in the GCC.

Renewable energy options such as wind and solar energy could also offer the region valuable alternative energy to fossil fuels in power generation and could also help in their UNFCCC commitments. The sections below delve deeper into the status of and policies for promoting renewable energy in individual GCC countries.

\subsubsection{Saudi Arabia}

The country's energy demand has been rising rapidly due to its economic and population growth, with total final energy consumption increased by about $74 \%$ from 2010 to 2016 . The growth is expected to continue. Saudi Arabia accounts for about half of the GCC's total final energy consumption and is the region's largest energy market. It is estimated that its

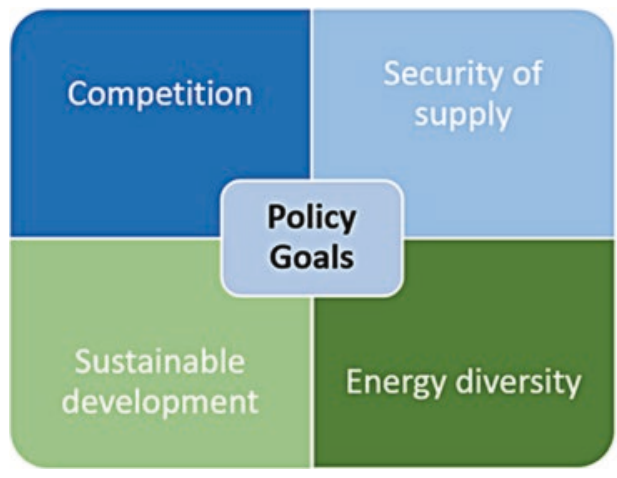

Economic Vision 2030, Bahrain Kuwait Energy Security Vision 2030 Qatar National Vision 2030 UAE Energy Strategy 2050 Oman Vision 2040 Oman Energy Master Plan 2040 Saudi Vision 2030

Fig. 8.1 Policy framework to accelerate RE in GCC countries. (Source: Author's description) 
potential to harness renewable energy exceeds that of its neighboring countries.

Saudi Arabia's renewable energy plans and strategies can be traced back to the 2000s when several institutions were founded to support the development of renewables. The initial target was planned by King Abdullah City for Atomic and Renewable Energy (K.A.CARE) for competitive procurement of $54 \mathrm{GW}$ of renewable energy by 2030 , later delayed to 2040 , was eventually abandoned (IRENA 2016b).

In the year 2016, Saudi Arabia came out with its long-term goals through a Saudi Vision 2030. In this vision document, Saudi Arabia plans to reduce its dependence on oil, diversify its economy, and develop public service sectors such as health, education, infrastructure, recreation, and tourism. In the vision document, Saudi Arabia set an initial target of 9.5 gigawatts of renewable energy. This target was to enable the renewable energy value chain in the Saudi electricity sector, including research and development, and manufacturing, among other stages (Kingdom of Saudi Arabia 2016).

However, Saudi Arabia revised its targets by establishing National Renewable Energy Program (NREP) under Renewable Energy Project Development Office (REPDO), Ministry of Energy. The NREP is a long term, a strategic initiative that directly supports the Kingdom's Vision 2030. The NREP will also enable jobs in the sector and accelerate economic development in Saudi Arabia. The NREP will also lead to the establishment of the renewable energy industry and create a conducive environment by coupling private sector investment and encouraging public-private partnerships (Renewable Energy Project Development Office 2016). In 2018, as per the first 5 year plan, Saudi Arabia's revised its renewable energy targets to $20 \mathrm{GW}$ solar, with an overall increase of renewable targets to $27.3 \mathrm{GW}$. REPDO has also set a $40 \mathrm{GW}$ target for solar and a $58.7 \mathrm{GW}$ target for renewables overall by 2030 (Renewable Energy Project Development Office 2019b).

In its NDC, Saudi Arabia outlined a plan which seeks to avoid up to 130 million tons of CO2eq by 2030 annually. Further, Saudi Arabia would invest and implement programs for renewable energy (including waste to energy) systems, to diversify its energy mix. In addition, in its NDC, Saudi Arabia could invest in energy efficiency programs, carbon capture and utilization/storage, and use of natural gas for electricity generation. (Kingdom of Saudi Arabia 2015). 
In the year 2017, Saudi Arabia's renewable capacity was only about $92 \mathrm{MW}$, mostly from solar PV projects and around $2 \mathrm{MW}$ of onshore wind projects. However, in March 2018, Saudi Arabia and Softbank signed a memorandum of understanding to construct about 200 gigawatts of solar power facilities by 20,303 but during the end of the year, the project was put on hold, although the Softbank and Public Investment Fund (PIF) are continuing to collaborate on solar energy plans. Further, in the same year, Saudi Arabia came out with its Small-Scale Solar PV Systems Regulations to promote distribution system connected small-scale solar PV systems in the Kingdom of Saudi Arabia, a set of rules, which will be applied to projects not exceeding $1 \mathrm{MW}$ (Electricity and Cogeneration Regulatory Authority 2017).

In October 2018, a new city powered entirely by renewable energy known as NEOM was announced by Saudi Crown Prince Mohammed bin Salman at the Future Investment Initiative conference in Riyadh. NEOM is set in North-Western Saudi Arabia and includes territory from Egypt and Jordan comprising a total area of $26,500 \mathrm{~km}^{2}$. The zone is intended to be pollution-free and fully powered by renewable energy, forward-looking energy storage, and transport solutions as well as R\&D and manufacturing. NEOM will be backed by more than $\$ 500$ billion by the Public Investment Fund of Saudi Arabia, as well as private investors (Government of Saudi Arabia 2018).

One of the important changes which occurred in Saudi Arabia's ministerial structure was the combining ministries for oil and electricity under one umbrella of Ministry for Energy, Industry and Mineral Resources that formally administers the NREP (International Renewable Energy Agency 2019). Under NREP, government with its intention to bring more solar power in its electricity mix carried out its lst phase of auctions, which was launched in 2018, with issuance of tenders for two projects Sakaka $300 \mathrm{MW}$ solar PV power plant in the northern region awarded to AWCA Power, which set a new world record with a bid of 2.34 cents/kWh backed by a 25-year Power Purchase Agreement (PPA) with the Saudi Power Procurement Company (SPPC) and the Dumat Al Jandal project of $400 \mathrm{MW}$, which will be Saudi Arabia's first utility-scale wind farm. Currently, Saudi Arabia invites bids for round two auction of 6 projects in two categories in line with NREP. REPDO's round two projects are $200 \mathrm{MW}, 300 \mathrm{MW}, 300 \mathrm{MW}$, and $600 \mathrm{MW}$ as category "B" solar PV projects and $20 \mathrm{MW}$ and $50 \mathrm{MW}$ as category "A" small solar PV projects (Renewable Energy Project Development Office 2019a, b). 
However, regulatory framework and policy instruments to achieve the country's renewable energy goals remain a challenge, since the private sector currently plays a minor role in the energy sector.

\subsubsection{Kuwait}

Kuwait relies almost exclusively on natural gas and oil products for electricity generation and its substantial desalination production. Each fuel currently accounts for about half of total energy consumption in the economy and per capita energy consumption in Kuwait is among the highest in the world. Electricity consumption grew, on average, by $5 \%$ per year from 2000 to 2015 and expected to grow even further (Kuwait Institute for Scientific Research 2019).

Although, renewable energy is in its early stages in Kuwait. However, there has been some major development in recent years mainly to diversify its energy mix and to mitigate rising environmental concerns. Kuwait Government has committed towards a highly ambitious plan to meet $15 \%$ of its energy requirements from renewable resources by 2030 .

As part of their NDC, the Kuwait Government has committed to reducing its greenhouse gas emissions through energy production from renewable energy. Further, Kuwait also wants to improve petroleum products by producing clean fuel according to environmental specifications to supply power plants with it by 2020 . The country also intends to construct a new refinery to replace the state's oldest refinery, which will meet international environmental standards. Kuwait also adopted a new Environment Protection Law to protect human health, control pollution, enhance natural resources, and promote energy efficiency and clean energy (The State of Kuwait 2015).

Kuwait's Vision 2035 and current Five-Year Development Plan (keeping aligned with its NDC) focuses on economic diversification and aims to position the country as a regional center for trade and finance. Kuwait's targets of renewable generation in their electric power system is to be $5 \%$ by 2020 and $15 \%$ by 2030 (IRENA 2016a, b: Table 8.2 ).

As of June 2019 , there has been a handful of small renewable energy projects . One of the most important demonstration projects has been the Al Shagaya renewable energy park consisting of $10 \mathrm{MW}$ of solar, $10 \mathrm{MW}$ of wind and, $50 \mathrm{MW}$ of concentrated solar power projects. (Ministry of Electricity \& Water 2019).

With the full completion of Shagaya phase 1, Kuwait is planning the phase 2 of the program with 1.5 GW of solar PV Park known as Dabdaba 
Table 8.2 Kuwait

renewable energy targets

\begin{tabular}{ll}
\hline RE sector & RE capacity by 2030 \\
\hline Solar PV & $4.6 \mathrm{GW}$ \\
Solar CSP & $5.7 \mathrm{GW}$ \\
Wind & $0.7 \mathrm{GW}$ \\
\hline
\end{tabular}

Source: IRENA

project, whose construction is overseen by Kuwait National Petroleum Company (Renewables Now 2019). Kuwait is still in the early stages of renewable energy project dissemination in the region but with upcoming low bids for renewable projects in the region, it will look to ramp up their efforts to promote renewable energy.

\subsubsection{United Arab Emirates}

UAE is the GCC's 2nd largest energy market after Saudi Arabia but despite that UAE is the front runner when it comes to implementing renewable energy projects into its energy mix. Like other Middle Eastern countries, majority of generation of electricity is met from natural gas, and much of it is imported. UAE consists of seven emirates, like any other GCC countries, each emirate in UAE has emphasized on shift and reduce the reliance on oil and gas for its energy needs by adopting alternating sources of energy. UAE is also a leading solar market in the Middle East.

The United Arab Emirates pledged to pursue "a strategy of economic diversification that will yield mitigation and adaptation co-benefits" as part of their NDC. The UAE has set a target to increase its share of renewable energy in its energy mix from $0.2 \%$ in 2014 to $24 \%$ by 2024 . The UAE also created the Ministry of Climate Change and Environment to make the climate one of the country's top priorities. Further, in other measure UAE seeks to reduce gas flaring, carbon capture and utilization/storage (United Arab Emirates 2015).

The UAE government in its UAE vision prioritized sustainable development both economically and socially through an increase in the share of clean energy. Further, in 2017, UAE launched "Energy Strategy 2050 " as its first unified energy strategy. The strategy aims to increase clean energy contribution in UAE's energy mix by $50 \%$ and reduce the carbon footprint of power generation by $70 \%$ till 2050 . The strategy targets an energy mix that combines renewable, nuclear and clean energy 
sources to meet the UAE's economic requirements and environmental goals. To achieve the above targets, UAE government is planning to invest approximately USD 163.35 billion by 2050 (UAE government 2017). UAE government has also developed the Green Growth Strategy in 2012, mainly focusing on becoming one of the world leaders in this area as well as a center for the export and re-export of green products and technologies. All these initiatives also emphasize on knowledge creation and technology innovation to support the job market in UAE.

Emirates in UAE are also playing their part in these initiatives through their individual efforts. Dubai revised its targets after a series of auctions, which revealed the declining price of solar. In 2015, Dubai increased its target of renewable energy by $15 \%$ by 2030 . Later same year they further revised the target by $25 \%$ by 2030 , mainly due to high solar potential (International Renewable Energy Agency 2019). In line with the vision and directives of UAE strategy, in 2012, Dubai announced its flagship project Mohammed bin Rashid Al Maktoum Solar Park owned by Dubai Electricity and Water Authority (DEWA) making it largest renewableenergy project in the world with a planned production capacity of $5000 \mathrm{MW}$ upon completion in 2030. This initiative is also a part of the Dubai Clean Energy Strategy 2050 that aims to make Dubai a global hub for green economy. In addition, The Dubai Clean Energy Strategy aims to achieve $75 \%$ of Dubai's energy from clean energy sources by 2050 in a phased manner (Government of Dubai 2019b).

The Mohammed bin Rashid Al Maktoum Solar Park consists of 5 phases. The lst phase started $13 \mathrm{MW}$ in 2012 and the power plant became operational at the end of the year 2013. The 2nd phase started in 2017, a $200 \mathrm{MW}$ project which was implemented by DEWA with a consortium led by ACWA Power from Saudi Arabia. In the 2nd phase, DEWA got the lowest bid of USD 5.6 cents per kWh, making it the lowest bid for the solar power project in the world. (International Renewable Energy Agency 2019). As a part of the 3rd phase, DEWA awarded the bid to Masdar-led consortium to develop the $800 \mathrm{MW}$ of the solar park, in the process set a world record by obtaining the lowest price of USD 2.99 cents per kWh. As of now, the first $200 \mathrm{MW}$ has been operational with the second and third phases being implemented in stages until 2020.

Further, in 2017, the 4th phase was launched for a largest single-site Concentrated Solar Power (CSP) project in the world. The project was awarded to a group of Saudi Arabia's ACWA Power, The Silk Road Fund, and China's Shanghai Electric. The 5th phase will include a development 
plan of $900 \mathrm{MW}$ for Mohammed bin Rashid Al Maktoum Solar Park as per the IPP model with the commissioning of projects starting from 2021 (Government of Dubai 2019a, b). Further, Dubai had also launched its Shams Dubai program for rooftop and small scale solar systems. The program encourages the installation of rooftop solar through residential households and building owners.

Similar to Dubai, other emirates like Abu Dhabi are not that far behind Abu Dhabi's Shams I CSP project was the largest renewable energy project in operation in the Middle East when launched in 2013 with a capacity of 100 MW. Further, Abu Dhabi's Noor Abu Dhabi Solar Power Project a $1177 \mathrm{MW}$ solar power plant became the world's biggest single-site solar power plant with the estimated development cost of USD 0.87 billion. The construction of the Noor Abu Dhabi Solar Power Project commenced in 2017 and began its commercial operations in 2019. It is expected that project could generate sufficient electricity to power approximately 195,000 homes and offset seven million tons a year of carbon emissions (NS Energy 2019a). Similar to Dubai, in late 2017, Abu Dhabi Distribution Company (ADDC), launched a program to allow residents and businesses to add solar panels on rooftops to reduce their electricity bills. Further, Emirate of Sharjah waste to energy facility will be the first of its kind in UAE. The facility will use around 37.5 tons $(t)$ of unrecyclable solid waste an hour to generate $30 \mathrm{MW}$ of electricity (NS energy 2019b).

\subsubsection{Qatar}

All the GCC countries are going through a population and economic growth phase, therefore, demand for utilities has also been increasing rapidly. Qatar is no exception to this growth. The Qatar Electricity and Water Company (QEWC) is one of the major companies in Qatar and among the first private sector companies in the region that operate in the field of electricity generation and water desalination. The company and its joint venture companies together have a capacity of over $10.590 \mathrm{GW}$ of electricity and over 481.5 MIGD of desalinated water as of year 2018 (Qatar Electricity and Water Company 2018). To support the sustainable development in the country and replacement of natural gas as replacement for oil in the power sector, Qatar government in 2018, came up published with its Qatar Vision 2030. The vision document provides a framework for national development strategies and a balance among economic growth, social and human development, and environmental protection (Qatar General Secretariat For Development Planning 2008). In line with 
the vision Qatar came out with its National Development Strategy 2011-2016 (NDS-1), the first comprehensive development strategy aimed at achieving vision goals of sustainable and balanced growth including responsible use of oil and human resources through developing and modernizing government institutions. Along the same lines, Qatar came out with NDS - 2 plan for 2018 till 2022.

Further, in 2nd development strategy, Qatari Government emphasized the use of renewable energy to limit pollution and gas emissions and generates economic returns. Although need for renewable energy in Qatar's energy system is very minimal, nevertheless, the Ministry of Energy and Industry (MoEI) is developing and implementing a renewable energy strategy along with its policy with legal framework. Also, Qatar General Electricity \& Water Corporation (Kahramaa) has developed a solar energy plan for $200 \mathrm{MW}$ to be developed by 2020 and option to increase it to $500 \mathrm{MW}$ after the completion of first phase (Ministry of Development Planning and Statistics 2018). The State of Qatar, in its NDC, kept focus on dealing with the potential impacts of climate change through promoting energy efficiency, clean and renewable energy, education, and research and development (Ministry of Environment, Qatar 2015). To date, Qatar foundation uses $3 \mathrm{MW}$ of PV capacity to power its campus. Other renewable energy projects such as Biogas and municipal waste accounted for about $38 \mathrm{MW}$ of power generation capacity in 2017. The Mesaieed plant is GCC's largest waste to energy facility with $30 \mathrm{MW}$ capacity, which also generates $8 \mathrm{MW}$ of biogas based power. Qatar is also working on small scale solar project, Qatar National Convention Center (NCC) installed a 667 KW capacity solar PV array. Similarly, Green Gulf also installed a 26 KW PV array at the national command center for Kahramaa (Alhaj 2017).

Although, regulatory framework and policy instruments are not satisfactory for private power producers, at the same time, need for renewable energy in the small country of Qatar is also very minimum. However Qatari government acknowledges climate change issues and need for sustainable development and environmental protection for its future generation, therefore, Qatari government is putting every possible positive step to address sustainability through renewable energy dissemination not only in energy sector but other sectors as well.

\subsubsection{Babrain}

Bahrain one of the smallest oil produces in GCC. Same as other GCC countries, the energy sector is almost completely dependent on fossil fuel, 
mainly natural gas and heavy fuel oil. Due to this, Kingdom of Bahrain looks to diversify its fuel supply to the power sector (EIA 2016). As of 2016, Bahrain had an installed generating capacity of about $4 \mathrm{GW}$, of which just $6 \mathrm{MW}$ was from renewable energy. Bahrain also gets a supply of electricity from GCC and ALBA interconnection links which is about $900 \mathrm{MW}$ in capacity (Electricity and Water Authority of Bahrain 2018). Just like any other GCC, Bahrain is going through a transformation with rapid growth in population and industrial development, demand for power is ever-growing in Bahrain. In October 2008, Kingdom of Bahrain launched its Economic vision 2030 which focused on protecting natural environment with direct investments to technologies that reduce carbon emissions, minimize pollution and promote the sourcing of more sustainable energy (Government of Bahrain 2008).

Bahrain, to diversify its energy mix, came out with its National Renewable Energy Action Plan (NREAP) in 2017. The Plan represents the implementation efforts of Bahrain's NDC commitments under the Paris Agreement, the United Nations Sustainable Development Goals, and the League of Arab States Renewable Energy Framework. NREAP sets a renewable energy (including waste to energy) target of 5\% by 2025 and $10 \%$ by 2035 in its energy mix. (Sustainable Energy Authority 2017) (Table 8.3)

Further, Bahrain's NDC also aims to reduce Bahrain's dependence on oil \& gas. The country thus emphasizes demonstrating PV solar technology under local conditions to support upscaling of renewable energy through BAPCO's 5 MW PV grid-connected plant. The project consists of the installation of 21,000 smart solar panels to generate a substantial number of electric units annually. Other mitigation efforts focus on energy efficiency in building, industry, transport and the energy sector (Kingdom

Table 8.3 Bahrain's renewable energy target

\begin{tabular}{|c|c|c|c|c|}
\hline \multirow[t]{2}{*}{ Renewable energy targets } & \multicolumn{2}{|l|}{2025} & \multicolumn{2}{|l|}{2035} \\
\hline & $M W$ & $G W h$ & $M W$ & $G W h$ \\
\hline Wind & 50 & 125 & 300 & 750 \\
\hline Solar & 200 & 340 & 400 & 680 \\
\hline Biogas & 5 & 13 & 10 & 26 \\
\hline Total & 255 & 478 & 710 & 1456 \\
\hline
\end{tabular}

Source: Sustainable Energy Unit of Bahrain 
of Bahrain 2015). As a step to fulfil its vision and policies, in March 2017, Bahrain's Electricity and Water Authority launched a tender for a solar park at Askar landfill, which was won by Saudi energy company ACWA Power with winning bid $\$ 0.039 / \mathrm{kWh}$. Similarly, the Solar Energy Unit of Bahrain in collaboration with the United Nations Development Program launched a $3 \mathrm{MW}$ tender for solar arrays at eight locations containing 66 government buildings (PV magazine 2019).

Kingdom of Bahrainis small island nation in GCC with very limited resources. Diversification to renewable energy will not only provide the country energy diversification but also enable the country to become self-sustainable.

\subsubsection{Oman}

In Oman, natural gas is the primary fuel for power generation and water desalination, whereas diesel is used in rural areas. Nearly a quarter of the domestic natural gas consumption comes from electricity generation and desalination plants with remaining by industrial and petrochemical sectors and rest is exported as Liquefied natural gas (LNG). With the rise in Oman's domestic requirements, the government is planning to diversify its energy mix. Oman has witnessed a robust compounded annual growth of $9.09 \%$ in peak electricity demand from 2010 to 2016 with available capacity rising from $4.05 \mathrm{GW}$ to $7.8 \mathrm{GW}$. The government of Oman came out with its National Energy Strategy 2040, which seeks to ensure the country's long-term energy sustainability. In its strategy, the government has set a target of at least $10 \%$ of electricity generation from renewables by 2025 and up to 3000 megawatts (MW) of coal-fired power plants by 2030. In addition, to previous target, the National Program for Enhancing Economic Diversification (Tanfeedh) has modified the target to $11 \%$ of electricity generation from renewable energy by 2023 . Similar goals were also integrated in Oman's Vision 2020 and the 5-Year Development Plan (2016-2020)(Hasan et al. 2019).

In their NDC, the Omani government aims to increase the share of renewable energy. Further, Oman will also seek funds, capacity building and transfer of technology from the UNFCCC for further efforts in development of renewable energy. Further, Oman mitigation contributions also include measures such as reducing gas flaring from oil industries and boosting energy efficiency (Ministry of Environment and Climate Affairs, Oman 2015). Table 8.4 shows the renewable energy development plan for 
Table 8.4 Renewable Energy Development Plan - MIS (MW)

\begin{tabular}{llllllll}
\hline & 2019 & 2020 & 2021 & 2022 & 2023 & 2024 & 2025 \\
\hline Ibri II solar IPP & - & - & - & 500 & 500 & 500 & 500 \\
Solar IPP 2022 & - & - & - & - & 500 & 500 & 500 \\
Solar IPP 2023 & - & - & - & - & - & 500 & 500 \\
Solar IPP 2024 & - & - & - & - & - & - & 500 \\
Wind IPP 2023 & - & - & - & - & - & 100 & 100 \\
Barka WTE IPP & - & - & - & - & 100 & 100 & 100 \\
Total capacity & - & - & - & 500 & 1100 & 1700 & 2200 \\
Capacity contribution & - & - & - & 100 & 295 & 430 & 530 \\
\hline
\end{tabular}

Source: OmanPWP

Oman's Main Interconnected Transmission System (MIS) Network, which supplies majority capacity for the country.

In view of the diversification of its energy resources and manage the rising growth of the energy sector, Oman is moving rapidly towards renewable energy projects. Oman announced its 500 MW Ibri Solar Project in December 2017, which was awarded to Saudi-based ACWA Power, Kuwait-based Gulf Investment Corporation and Kuwait-based Alternative Energy Projects Company in 2019 through competitive bidding process (Times of Oman 2019). Similarly, 105 MW Amin Solar PV Project was awarded to a consortium led by Marubini in 2018. Oman has an extensive coastline and vast unpopulated areas; therefore, wind power project can contribute significantly to the future electricity supply of the country. Masdar owned Dhofar Wind Power Project will have an installed capacity of 50 megawatts, making it the first large-scale wind farm in GCC (Masdar Clean Energy 2019). To promote the wind energy in Oman, the Oman Power and Water Procurement Company (OPWP) has created a wind atlas for Oman and will conduct a wind resource assessment to collect wind data for future wind energy projects (business live me 2019).

The Rural Areas Electricity Company (RAECO) (Tanweer) identified 11 sites for a technical and economic feasibility study to implement solardiesel hybrid projects with a total of $42 \mathrm{MW}$ capacity. RAECO also started purchasing electricity for 20 years from the 307 kilowatt-capacity project operated by Bahwan Astonfield Solar Energy Company, Oman's first commercial solar power project in 2015 inaugurated in $\mathrm{Al}$ Mazyona. Further, RAECO, under the "SAHIM" initiative introduced by Authority for Electricity Regulation (AER), has also formulated a plan to implement the 
regulatory framework by establishing a team to activate the solar energy implementation of small and medium-scale grid-connected solar systems to all customers (Tanweer 2018).

The SAHIM initiative was launched in May 2017 by the Oman Authority for Electricity Regulation (AER) and had two phases. The SAHIM I allows large households and businesses to install small-scale grid-connected PV systems at their own cost. Whereas, SAHIM II is aimed at promoting small-scale grid-connected PV systems for around $10 \%$ to $30 \%$ of residential sector as competitive bidding for private developers as per the build, own and operate machinery. If this plan is realized, it would reduce the government's annual subsidy bill. Oman government is also been promoting in the rural and mountain regions of Oman (Oman Authority of Electricity Regulation 2017). If SAHIM is realized the prospective benefits for Oman are as follows, gas savings over 25 years of between 2 billion $\mathrm{Sm}^{3}$. Further $\mathrm{Co}_{2}$ emission reduction over 25 years of about 3.2 million tons with average reduction in customer bills of around 42\% (Ghaithi 2017).

Oman had also developed 1.021 GW of a solar thermal facility located in south of Oman. The steam generated from the thermal power plant is utilized for thermal enhanced oil recovery (EOR) to extract heavy and viscous oil at the Amal oilfield. With the successful implementation of the solar EOR project, Petroleum Development Oman plans to add another four blocks beginning from 2019 (Power technology 2016).

Oman among GCC countries is an example when it comes to the liberalization of the electricity sector. With this liberalization and vision to diversify its energy sources. Oman is poised to become one of the leading markets in renewable energy in GCC.

\subsection{Challenges to Promoting Renewable Energy in GCC Countries}

Rising electricity demand, economic and environmental constraints have encouraged governments in the Gulf Cooperation Council (GCC) region to consider integration of renewable energy in their electricity mix. However, delivering renewable energy targets requires robust policies, finance, and technological framework. A homegrown creative solution is needed for the GCC countries to tackle rising energy consumption and population. Utilities/independent power producers (IPPs) are provided 
with subsidized fuel for power generation. Removing price distortion in the supply side in GCC region, and price reform measures are crucial for addressing the concern. At the same time electricity to residential sector in most of the GCC countries is highly subsidized, which makes dissemination of distributed renewable (solar) energy very difficult.

Most of the national electricity markets in the GCC region are vertically integrated, that is owned, operated and built by state or have a single buyer model. Liberalization of national electricity markets is desirable but not a prerequisite. Several countries in the region, including Saudi Arabia, Oman, Abu Dhabi, and Dubai have established electricity regulators who face the daunting challenge of balancing the interests of consumers, companies, and governments. But, for renewable energy, GCC countries are adopting a policy framework to encourage independent power producers and private entities (King Abdullah Petroleum Studies and Research Center 2018a, b).

Currently, renewable energy projects are entirely government-led projects but strong policies and regulatory frameworks are needed to attract private sector investments. At present policy instruments are either weak or absent, therefore, they are unable to attract market players. Some of the initiatives are needed for grid-connected renewable energy that should cover incentives, facilitation, and clearances for private power producers. There should be enabling regulatory provisions in place such as tariff determination for different technologies, provisions of trading and evacuation of power. There should be a creation of supplementary market for meeting the grid-related challenges from solar and wind (Hasan 2019).

The GCC countries should also focus on capacity building in terms of manufacturing or services in the sector for renewable energy projects. All the GCC countries acknowledge the fact that the benefits of renewable energy into their energy mix but in the GCC countries the biggest challenge will be to create energy consciousness and awareness to use the energy in smarter ways among general public. The GCC countries have the resources and capability to address these challenges, especially, the recent development in renewable energy sector has commendable. But they need to act on these challenges rather sooner than later. 


\subsection{Harnessing the Renewable Energy Opportunity In GCC Countries}

The GCC is a hydrocarbon driven market and most of its energy needs come from fossil fuel. The Gulf Cooperation Council (GCC) nations, such as Saudi Arabia, Bahrain, Kuwait, Oman, Qatar, and United Arab Emirates, have come up with vision and strategy to set different renewable energy dissemination plans for next decade or so. However, According to The World Bank data, GCC countries are among the top 25 countries contributing to carbon dioxide emissions per capita, with high carbon footprint and rapid urbanization \& socio-economic growth. The GCC countries are more determined to increase the share of renewable energy in their total energy mix (The World Bank 2014).

The GCC region has considerable renewable energy potential, particularly for solar photovoltaic (PV) generation, making it a favorable market for solar generation (Table 8.5). Tapping into the renewable energy market will not only provides a medium for low carbon footprint but also can address rapid urbanization and socio-economic growth.

Renewable energy, especially, solar and wind can bring socio-economic benefits to all the GCC countries. The GCC countries are expected to gain, if they achieve their targets by 2030, can save about 354 million barrels of oil equivalent in power sector. Further, the region can reduce about 136 million tons of CO2. The GCC region can not only on its fossil fuel resources and reduce its $\mathrm{CO} 2$ emissions but can also create more than 0.22 million direct jobs (International Renewable Energy Agency 2019).

The water and energy sectors are interlinked in the GCC countries and one of the most important commodities. The GCC is among the most water-stressed regions in the world with very limited water resources. This makes renewable energy technology even more important, especially in power sector, since water is very important in fuel extraction and processing as well as for power generation. The GCC countries can save about 11.5 trillion liters of water through renewable energy from power production and fuel extraction for power extraction (International Renewable Energy Agency 2019).

Apart from socio-economic gains from renewable energy, the GCC countries can also pioneer in the renewable energy sector by creating awareness and become example in front of the whole world through high capacity power projects. The GCC countries have the opportunity to be a 
Table 8.5 Renewable Energy Projects in GCC

\begin{tabular}{|c|c|c|c|c|c|}
\hline Country & Project/site & Technology & Size $(M W)$ & Status & $\begin{array}{l}\text { Expected start } \\
\text { of operation }\end{array}$ \\
\hline \multirow{18}{*}{$\begin{array}{l}\text { United } \\
\text { Arab } \\
\text { Emirates } \\
\text { (Dubai) }\end{array}$} & \multirow{6}{*}{$\begin{array}{l}\text { Mohammed bin } \\
\text { Rashid Al } \\
\text { Maktoum Solar } \\
\text { Park, phase IV }\end{array}$} & \multirow[t]{4}{*}{ CSP } & \multirow[t]{4}{*}{700} & \multirow{4}{*}{$\begin{array}{l}\text { Contracts } \\
\text { awarded }\end{array}$} & \multirow{6}{*}{$\begin{array}{l}\text { To come } \\
\text { online in } \\
\text { stages } \\
\text { starting in } \\
2020 \\
\text { Assumed } \\
2020 \\
\text { onwards }\end{array}$} \\
\hline & & & & & \\
\hline & & & & & \\
\hline & & & & & \\
\hline & & \multirow[t]{2}{*}{ Solar PV } & \multirow[t]{2}{*}{250} & & \\
\hline & & & & & \\
\hline & \multirow{4}{*}{$\begin{array}{l}\text { Mohammed bin } \\
\text { Rashid Al } \\
\text { Maktoum Solar } \\
\text { Park, phase III }\end{array}$} & \multirow[t]{4}{*}{ Solar PV } & 600 (of & Construction & \multirow[t]{4}{*}{2020} \\
\hline & & & \multirow[t]{2}{*}{$800)$} & \multirow{2}{*}{$\begin{array}{l}\text { has begun in } \\
2017\end{array}$} & \\
\hline & & & & & \\
\hline & & & $800)$ & $\begin{array}{l}\text { The first stage of } \\
200 \mathrm{MW} \\
\text { completed in } \\
\text { May } 2018\end{array}$ & \\
\hline & Mohammed bin & \multirow[t]{4}{*}{ Solar PV } & \multirow[t]{4}{*}{200} & \multirow{4}{*}{$\begin{array}{l}\text { Completed in } \\
\text { March } 2017\end{array}$} & \multirow[t]{4}{*}{2017} \\
\hline & Rashid Al & & & & \\
\hline & Maktoum Solar & & & & \\
\hline & Park, phase II & & & & \\
\hline & Mohammed bin & \multirow[t]{4}{*}{ Solar PV } & \multirow[t]{4}{*}{13} & \multirow[t]{4}{*}{ Completed } & \multirow[t]{4}{*}{2013} \\
\hline & Rashid Al & & & & \\
\hline & Maktoum Solar & & & & \\
\hline & Park, phase I & & & & \\
\hline \multirow{4}{*}{$\begin{array}{l}\text { United } \\
\text { Arab } \\
\text { Emirates } \\
\text { (Abu } \\
\text { Dhabi) }\end{array}$} & Noor Abu & \multirow[t]{2}{*}{ Solar PV } & \multirow[t]{2}{*}{1177} & \multirow{2}{*}{$\begin{array}{l}\text { Under } \\
\text { construction }\end{array}$} & \multirow[t]{2}{*}{2019} \\
\hline & Dhabi, Sweihan & & & & \\
\hline & Shams 1 & CSP & 100 & Completed & 2013 \\
\hline & & & & & \\
\hline \multirow[t]{5}{*}{ Oman } & Dhofar, phase I & Wind & 50 & $\begin{array}{l}\text { EPC contract } \\
\text { awarded }\end{array}$ & 2020 \\
\hline & $\begin{array}{l}\text { Dhofar, phase II } \\
\text { wind } 150\end{array}$ & Wind & 150 & Planned & 2023 \\
\hline & $\begin{array}{l}\text { Miraah solar } \\
\text { thermal }\end{array}$ & $\begin{array}{l}\text { Solar } \\
\text { thermal }\end{array}$ & $\begin{array}{l}1000 \\
\text { (GWth) }\end{array}$ & $\begin{array}{l}\text { Under } \\
\text { construction }\end{array}$ & $\begin{array}{l}100 \mathrm{MW} \\
\text { complete, } \\
\text { delivering } \\
660 \text { tons of } \\
\text { steam/day as } \\
\text { of February } \\
2018\end{array}$ \\
\hline & Ibri PV plant & Solar PV & 500 & $\begin{array}{l}\text { Companies } \\
\text { shortlisted }\end{array}$ & Early 2021 \\
\hline & $\begin{array}{l}\text { PDO Amin PV } \\
\text { plant }\end{array}$ & Solar PV & 100 & $\begin{array}{l}\text { Contract } \\
\text { awarded }\end{array}$ & \\
\hline
\end{tabular}


Table 8.5 (continued)

\begin{tabular}{|c|c|c|c|c|c|}
\hline Country & Project/site & Technology & Size $(M W)$ & Status & $\begin{array}{l}\text { Expected start } \\
\text { of operation }\end{array}$ \\
\hline \multirow[t]{3}{*}{$\begin{array}{l}\text { Saudi } \\
\text { Arabia }\end{array}$} & Sakaka & Solar PV & 300 & $\begin{array}{l}\text { Under } \\
\text { construction }\end{array}$ & $\begin{array}{l}\text { To begin } \\
\text { commercial } \\
\text { operation in } \\
2019\end{array}$ \\
\hline & $\begin{array}{l}\text { Dumat Al } \\
\text { Jandal }\end{array}$ & Wind & 400 & $\begin{array}{l}\text { Bids received; } \\
\text { expected to be } \\
\text { awarded start of } \\
2019\end{array}$ & \\
\hline & Waad Al-Shamal & CSP & 50 & Completed & \\
\hline \multirow[t]{2}{*}{ Qatar } & Al-Kharsaag & Solar PV & 700 & Bids received & $\begin{array}{l}2020 \text { (first } \\
350 \mathrm{MW})\end{array}$ \\
\hline & $\begin{array}{l}\text { Mesaieed waste } \\
\text { to energy }\end{array}$ & $\begin{array}{l}\text { Waste to } \\
\text { energy }\end{array}$ & 38 & Completed & \\
\hline \multirow[t]{4}{*}{ Kuwait } & Shagaya & CSP & 50 & Completed & \\
\hline & & Solar PV & 10 & Completed & \\
\hline & & Wind & 10 & Completed & \\
\hline & $\begin{array}{l}\text { Al Dibdibah/ } \\
\text { Shagaya phase } \\
\text { II }\end{array}$ & Solar PV & $1200-1500$ & Bids invited & 2022 \\
\hline \multirow[t]{2}{*}{ Bahrain } & Askar landfill & Solar PV & 100 & $\begin{array}{l}\text { Request for } \\
\text { concept }\end{array}$ & $\begin{array}{l}\text { December } \\
2019\end{array}$ \\
\hline & Al Dur & $\begin{array}{l}\text { Solar-wind } \\
\text { hybrid }\end{array}$ & 5 & & \\
\hline
\end{tabular}

Source: IRENA

state of the art renewable energy hub through research and development, creating universities and academia programs.

Further, renewable energy or alternative sources of energy can also provide a diversification option to transportation fuel in the region. The electrification of vehicle fleet using alternate sources of clean energy can offer opportunity to tap renewable sources even further.

The GCC countries have limitless opportunities to be a global leader in the renewable energy landscape from state of the art project developers to the manufacturers of renewable energy equipment. With current trends in the GCC energy landscape, it is foreseeable that they can be the biggest players in the renewable energy markets globally. 


\subsection{Conclusion}

Renewable energy has taken long strides in the GCC countries over the past 5 years, but still has a long way to go in the GCC. There is a patterned shift in energy mix of the GCC countries. The GCC countries are now more focused than before for tapping renewable energy in their energy mix. But GCC countries still require a regulatory framework and financing structure for promoting renewable energy. The institutions, especially, think tanks in the region should work in close coordination with relevant national-level entities and, more importantly, with electricity regulators, transmission companies and system operators.

In GCC countries most of the projects are grid-connected utility-scale projects but GCC countries should try to go beyond that by promoting distributed renewable energy projects, which often provides a sustainable way of electricity generation options for the rural and farfetched areas.

Renewable energy, primarily solar energy will likely play an important part in its future energy mix, although there is a drastic difference between the deployments of renewable energy in different countries in the GCC region. The GCC countries, in the long run, can easily link the costeffectiveness of solar power to oil. The potential additional benefits that renewables energy brings for the region, most importantly environmental mitigation of the high per capita fossil fuel use and $\mathrm{CO}_{2}$ emissions, and through new industrial diversification, are immense.

Policymakers and stakeholders in the GCC have an excellent opportunity to capitalize on global trends in renewable energy for rapid deployment. Specifically, the region is well suited for renewable energy, especially, solar and wind deployment. If GCC countries are able to successfully and sustainably deploy renewable energy projects, the overall sector may see increased participation and diversification in the future.

\section{REFERENCES}

Alhaj, M. 2017. Implementation of Rooftop Solar PV in Qatar Through the Roof Rental Business Model. Modern Environmental Science and Engineering 3: 116-117.

business live me. 2019. OPWP Announces Slew of Renewable Energy Projects. Muscat: s.n.

EIA. 2016. Bahrain Overview. s.l: .EIA.

Electricity and Cogeneration Regulatory Authority. 2017. Small-Scale Solar PV Systems Regulations. Riyadh: Electricity and Cogeneration Regulatory Authority. 
Electricity and Water Authority of Bahrain. 2018. EWA Statistics 2018. s.1.: Electricity and Water Authority of Bahrain.

Ghaithi, H.A. 2017. Promoting Solar Rooftop in Oman: Policies, Regulations \& Outlook. Muscat: Oman Authority of Electricity Regulation.

Government of Bahrain. 2008 Economic Vision 2030. s.l.: Government of Bahrain. Government of Dubai. 2019a. Key Solar Projects and Programmes in Dubai. Dubai: Dubai Solar Show.

- 2019b. Mohammed bin Rashid Al Maktoum Solar Park. Dubai: s.n.

Government of Saudi Arabia. 2018. Neom. s.l.: Government of Saudi Arabia.

Hasan, S. 2019. Renewable Energy in GCC: Need for a Holistic Approach. EcoMENA, 19 June.

Hasan, S. et al. 2019. Oman Electricity Sector: Features, Challenges and Opportunities for Market Integration. King Abdullah Petroleum Studies and Research Center (KAPSARC).

International Renewable Energy Agency. 2019. Renewable Energy Market AnalysisGCC 2019. s.1.: International Renewable Energy Agency.

IRENA. 2016a. IRENA's Renewable Energy Roadmap. s.l.: IRENA. . 2016b. Renewable Energy Market Analysis. s.l: .IRENA.

KAPSARC. 2017. Future of the Electricity System in GCC Countries. Riyadh: King Abdullah Petroleum Studies and Research Center.

King Abdullah Petroleum Studies and Research Center. 2018. Electricity Market Integration in the GCC and MENA: Imperatives and Challenges. s.l.: King Abdullah Petroleum Studies and Research Center.

Kingdom of Bahrain. 2015. UNFCCC. [Online]. Available at: https://www4. unfccc.int/sites/submissions/INDC/Published\%20Documents/Bahrain/1/ INDC_Kingdom_of_Bahrain.pdf. Accessed 15 Sept 2019.

Kingdom of Saudi Arabia. 2015. UNFCCC. [Online]. Available at: https:// www4.unfccc.int/sites/submissions/INDC/Published\%20Documents/ Saudi\%20Arabia/1/KSA-INDCs\%20English.pdf. Accessed 15 Sept 2019.

- 2016. Vision 2030. Riyadh: Government of Saudi Arabia.

Kuwait Institute for Scientific Research. 2019. Kuwait Energy Outlook. s.1: .UNDP. Masdar Clean Energy. 2019. Dhofar Wind Project. Abu Dhabi: s.n.

Ministry of Development Planning and Statistics. 2018. Qatar Second National Development Strategy 2018-2022.s.1: .Ministry of Development Planning and Statistics.

Ministry of Electricity \& Water. 2019. First Statistical Year Book Electricity and Water. s.l.: Ministry of Electricity \& Water.

Ministry of Environment and Climate Affairs, Oman. 2015. UNFCCC. [Online]. Available at: https://www4.unfccc.int/sites/ submissions/INDC/Published\%20Documents/Oman/1/OMAN\%20 INDCs.pdf. Accessed 15 Sept 2019.

Ministry of Environment, Qatar. 2015. UNFCCC. [Online]. Available at: https:// www4.unfccc.int/sites/submissions/INDC/Published\%20Documents/ 
Qatar/1/Qatar\%20INDCs\%20Report\%20-English.pdf. Accessed

Sept 2019.

NS Energy. 2019a. Noor Abu Dhabi Solar Power Project. s.1.: s.n.

- 2019b. Sharjah Waste-to-Energy Project. s.l.: s.n.

Oman Authority of Electricity Regulation. 2017. SAHIM.s.1: .Oman Authority of Electricity Regulation.

Power technology. 2016. Miraah Solar Thermal Project. s.l: .Power technology.

PV magazine. 2019. ACWA Wins Babrain's 100 MW PV Tender with Bid of $\$ 0.039 / k W h$. s.1.: s.n.

Qatar Electricity and Water Company. 2018. QEWC Annual Report 2018. s.1: .Qatar Electricity and Water Company.

Qatar General Secretariat For Development Planning. 2008. Qatar National Vision 2030. s.l: .Qatar General Secretariat For Development Planning.

Renewable Energy Project Development Office. 2016. National Renewable Energy Program (NREP). Riyadh: s.n.

- 2019a. Saudi Arabia Invites Bids for Round Two of the National Renewable Energy Program. Riyadh: Renewable Energy Project Development Office.

- 2019b. Saudi Arabia Renewable Energy Targets and Long Term Visibility. Riyadh: REPDO.

Renewables Now. 2019. https://renewablesnow.com. [Online]. Available at: https://renewablesnow.com/news/kuwait-plans-2-gw-shagaya-tender-incurrent-fiscal-year-660071/. Accessed 16 Oct 2019.

Sustainable Energy Authority. 2017. National Renewable Energy Action Plan (NREAP). s.l.: January.

Tanweer. 2018. Renewable Energy. s.l: .Tanweer.

The State of Kuwait. 2015. UNFCCC. [Online]. Available at: https://www4. unfccc.int/sites/submissions/INDC/Published\%20Documents/Kuwait/1/ Kuwait_INDCs_English_Version.pdf. Accessed 15 Sept 2019.

The World Bank. 2014. CO2 emissions (metric tons per capita). s.1.: The World Bank.

Times of Oman. 2019. OPWP awards 500MW Ibri II solar IPP. Business Energy, 17 March.

UAE government. 2017. UAE Energy Strategy 2050. s.1.: UAE government.

United Arab Emirates. 2015. UNFCCC. [Online]. Available at: https://www4. unfccc.int/sites/submissions/INDC/Published\%20Documents/United\%20 Arab\%20Emirates/1/UAE\%20INDC\%20-\%2022\%20October.pdf. Accessed 15 Sept 2019.

World Economic Forum. 2017. Why Oil-rich Gulf Countries Need to Invest in Renewable Energy. Agenda, 15 May. 
Open Access This chapter is licensed under the terms of the Creative Commons Attribution 4.0 International License (http://creativecommons.org/licenses/ by $/ 4.0 /)$, which permits use, sharing, adaptation, distribution and reproduction in any medium or format, as long as you give appropriate credit to the original author(s) and the source, provide a link to the Creative Commons licence and indicate if changes were made.

The images or other third party material in this chapter are included in the chapter's Creative Commons licence, unless indicated otherwise in a credit line to the material. If material is not included in the chapter's Creative Commons licence and your intended use is not permitted by statutory regulation or exceeds the permitted use, you will need to obtain permission directly from the copyright holder. 